\title{
Effect of Nickel and Hexavalent Chromium on the Haematology of the Common carp, Cyprinus carpio
}

\author{
A.J Thatheyus* \\ $P G \&$ Research Department of Zoology, the American College, Madurai-2
}

Received: August 24, 2018; Accepted: September 12, 2018; Published: September 17, 2018

*Corresponding author: A.J Thatheyus, PG \& Research Department of Zoology, the American College, Madurai-2; E-mail: jthatheyus@yahoo.co.in

\begin{abstract}
Fingerlings of common carp were exposed to 2.5, 5.0 and 10.0 ppm of nickel and 15, 30 and 60 ppm of hexavalent chromium for 10 20 and 30 days. Both the metals induced altera $\urcorner$ tion in the Red and White blood cell pattern of fish. Influence of metal concentration and exposure period on the blood cell pattern was studied applying two way analysis of variance.
\end{abstract}

Keywords: Cyprinus Carpio; Nickel; Chromium; RBC Count; WBC Count; Haematology

\section{Introduction}

In mammalian toxicology, clinical methods are well estab $\neg$ lished to evaluate the physiological effects of toxicants. The use of such methods is based upon a good knowledge of normal clinical values and of the relationship between physiological and biochemical alterations, and important whole animal responses. Similar knowledge has not been gained yet in fish toxicology and work is going on in transferring of various clinical methods from medical and veterinary science to fish physiology and toxicology [1]. Haematological procedures are used in the diagnosis of diseases and parasite attacks in fish. They are altered by both environmental and endogenous factors. Several toxicants induce disturbances in the red and white blood cell pattern in fish including heavy metals, pesticides, industrial effluents and other chemicals. In the present work, an attempt has been made to study the effect of nickel and hexavalent chromium on the red and white blood cell count of common carp after chronic exposure.

\section{Materials and Methods}

Common carp fingerlings weighing 5+0.2 g were brought from a private farm and acclimatized in the laboratory for a week. Based on the 96h LC50 values of nickel and chromium, 47 and 347 ppm respectively, to common carp, sub lethal concentrations of nickel 2.5, 5 and $10 \mathrm{ppm}$ and of chromium 15, 30 and 60 ppm were chosen. Fish were exposed to the above mentioned concentrations for 30 days. During acclimatization and experimentation, fish were fed with artificially prepared diet. After 10, 20 and 30 days blood was taken from the caudal peduncle of fish exposed to each one of the concentrations. Both in the control and experimental fish both RBC and WBC count were esti $\neg$ mated following Johansson-sjobeck and Larsson [2]. The given values represent the mean of three observations. A computerized two-way analysis of variance [3] was applied to find out the signifi $\neg$ cance of variation caused by metal concentration and exposure period on RBC and WBC count.

\section{Results}

Both nickel and chromium treatment resulted in the decline of RBC count in common carp. But among the test concentrations, decrease in RBC count was more pronounced with the increase in concentration for nickel while the opposite trend was observed for chromium. For nickel treatment, in general, 20 days of expo $\neg$ sure produced more pronounced effect than 10 or 30 days of expo $\urcorner$ sure. For chromium treatment, after 30 days of exposure, decline in RBC count was noticed with the increase in chromium concentration (Fig.1 and 2). Decline in WBC count was observed

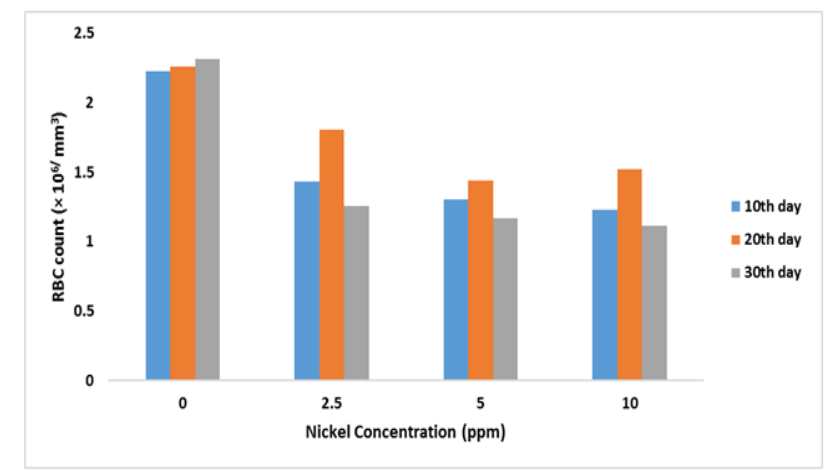

Figure 1: Effect of nickel on the RBC count of $C$. carpio communis

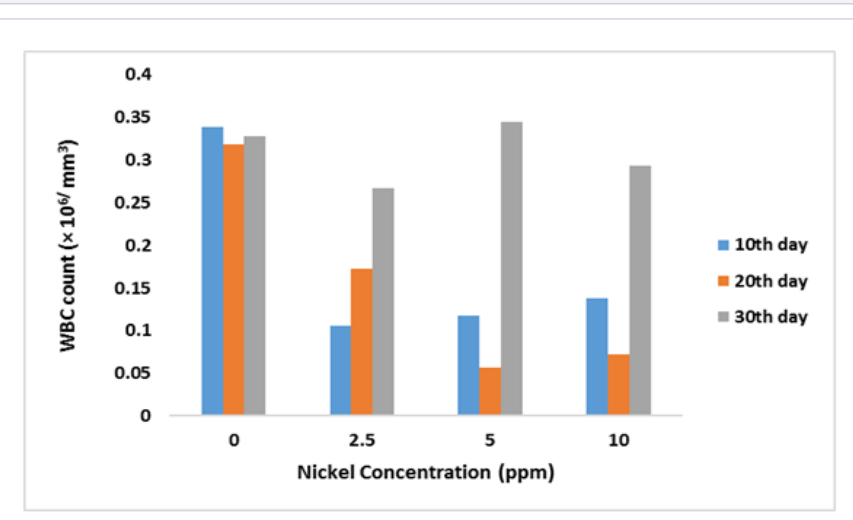

Figure 2: Effect of nickel on the WBC count of C. carpio communis 
for both nickel and chromium treatment. But among the test concentrations, in general, WBC count was directly proportional to concentration and exposure period. After 30 days of exposure,

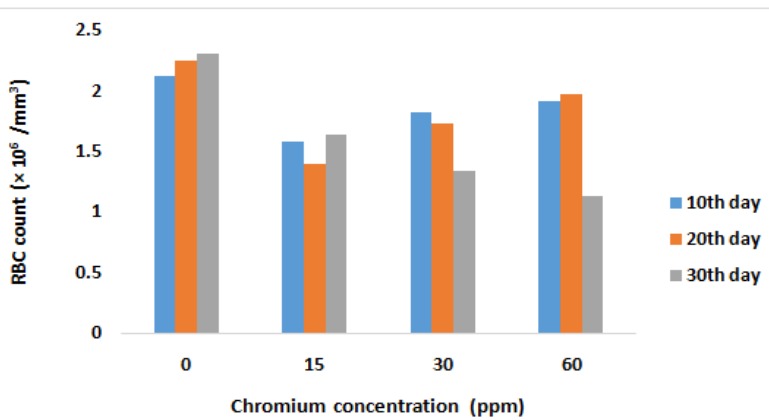

Figure 3: Effect of chromium on the RBC count of $C$. carpio communis

\section{Discussion}

A definite decline in $\mathrm{RBC}$ and $\mathrm{WBC}$ count in fish blood was observed due to nickel and chromium exposure. Similar observations were reported in Coho salmon due to zinc and pulp mill effluent treatment [4]. Reduction in RBC count was also noted in Anabas testudineus treated with textile mill effluent [5], and Puntius conchonius [6], Pleuronectes flesus [7], Colisa fasciatus [8] and Sarotherodon mossambicus [9-10] treated with cadmium. The reasons that can be attributed for the reduction in RBC count are inhibition of erythrocyte production, increase in the rate
WBC count in fish exposed to chromium approached normal values. (Fig.3 and 4).

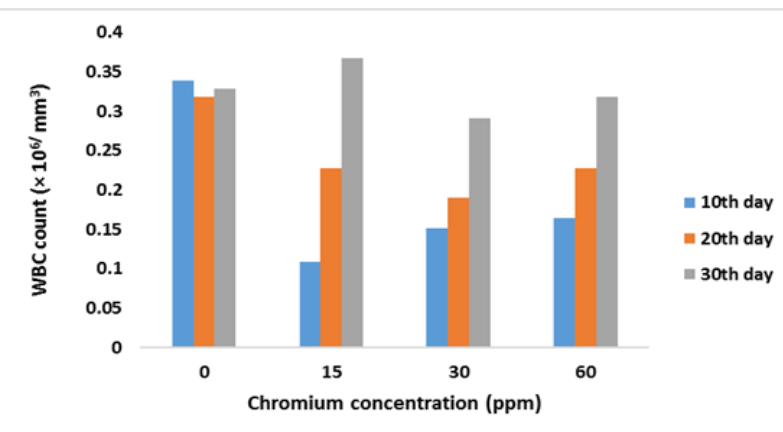

Figure 4: Effect of chromium on the WBC count of $C$. carpio communis

of erythrocyte destruction [11], haemodilution [12-13] due to gill damage or impaired osmoregulation [1] and destruction of haemato- poietic tissues [14].

In contrast, increase in blood cell count was observed in Mystus vittatus exposed to copper and zinc [15]. They predicted the reason as over compensation of the fish erythropoietically to make good the reduced oxygen carrying capacity of blood caused by $\mathrm{Cu}$ and $\mathrm{Zn}$ exposure. It is also reported metal ions stimulating erythropoiesis [16]. Similar reports were given by Larsson et al. [17], Haniffa and Isaiarasu [18] and Haniffa et al. [19].

Table 1: Two-way Analysis of Variance (ANOVA): Variations due to exposure period and concentration for the factors RBC count and WBC count during nickel and chromium exposure individually

\begin{tabular}{|c|c|c|c|c|c|c|c|c|}
\hline Heavy Metal & Factor & Variables & ss & df & MS & $\begin{array}{l}\text { Calculated } \\
\text { F Value }\end{array}$ & $\begin{array}{l}\text { Table Value } \\
\text { at } 5 \% \text { level }\end{array}$ & $\begin{array}{c}\text { Level of } \\
\text { Significance }\end{array}$ \\
\hline \multirow{4}{*}{ Nickel } & \multirow{2}{*}{ RBC count } & $\begin{array}{l}\text { Exposure } \\
\text { period }\end{array}$ & 0.18 & 2 & 0.09 & 5.32 & 5.14 & S \\
\hline & & $\begin{array}{c}\text { Exposure } \\
\text { concentration }\end{array}$ & 1.92 & 3 & 0.64 & 37.19 & 4.75 & S \\
\hline & \multirow{2}{*}{ WBC count } & $\begin{array}{l}\text { Exposure } \\
\text { period }\end{array}$ & 0.06 & 2 & 0.03 & 5.66 & 5.14 & S \\
\hline & & $\begin{array}{c}\text { Exposure } \\
\text { concentration }\end{array}$ & 0.05 & 3 & 0.02 & 3.65 & 4.76 & NS \\
\hline \multirow{4}{*}{ Chromium } & \multirow{2}{*}{ RBC count } & $\begin{array}{l}\text { Exposure } \\
\text { period }\end{array}$ & 0.16 & 2 & 0.08 & 1.04 & 5.14 & NS \\
\hline & & $\begin{array}{c}\text { Exposure } \\
\text { concentration }\end{array}$ & 0.87 & 3 & 0.29 & 3.74 & 4.76 & NS \\
\hline & \multirow{2}{*}{ WBC count } & $\begin{array}{l}\text { Exposure } \\
\text { period }\end{array}$ & 0.04 & 2 & 0.02 & 6.08 & 5.14 & S \\
\hline & & $\begin{array}{c}\text { Exposure } \\
\text { concentration }\end{array}$ & 0.02 & 3 & 0.008 & 2.58 & 4.76 & NS \\
\hline
\end{tabular}


In the present study both nickel and chromium were found to induce decline in RBC and WBC count of common carp. But in the long-term treatment with both nickel and chromium, WBC count approached normal values. Similar changes were seen in the physiological behavior of fish like food intake, appetite and growth. Due to toxicant induced stress initially but later fish could acclimate at least to sub lethal concentrations of toxicants [20-21]. Evidences for acclimatory trends for toxicant induced changes in numerous blood parameters have also been documented [2223]. Nickel induced more conspicuous alterations both in RBC and WBC count of common carp than chromium. Hence this type of haematological techniques can be used as diagnostic tools to reveal physiological effects of toxicants at sub lethal levels.

\section{Acknowledgements}

The author thanks the authorities of The American College, Madurai for encouragement.

\section{References}

1. Larsson A, Haux C, Sjobeck ML. Fish physiology and metal pollution: results and experiences from laboratory and field studies. Ecotoxicol Environ Saf. 1985;9(3):250-281.

2. Johansson-Sjobeck ML, Larsson A. The effect of cadmium on the hematology and on the activity of $\delta$-aminolevulinic acid dehydratase (ALA-D) in blood and hematopoietic tissues of the flounder Pleuronectes flesus L. Environ Res. 1978;17(2):191-204.

3. Zar JH. Biostatistical analysis. 2nd edition. Prentice-Hall, Englewood Cliffs, USA. 1984:176-179.

4. McLeay DJ. Sensitivity of blood cell counts in juvenile Coho salmon (Oncorhynchus kisutch) to stressors including sub lethal concentrations of pulp mill effluent and zinc. J Fish Res Board Can. 1975;32(12):23572364.

5. Murugesan AG, Haniffa MA. Effects of textile mill effluent on haematological changes of the obligatory air breathing fish, Anabas testudineus (Bloch), Dalela RC, Mane UE (Eds). The Academy of Environmental Biology, Muzaffarnagar, India. 1985.

6. Gill TS, Pant JC. Erythrocytic and leukocytic responses to cadmium poisoning in a freshwater fish, Puntius conchonius Ham. Environl Res. 1985;36(2):327-337.

7. Johansson-Sjobeck ML, Larsson A. Effects of inorganic lead on $\delta$-aminolevulinic acid dehydratase activity and hematological variables in the rainbow trout, Salmo gairdnerii. Arch Environ Contam Toxicol.1979;8(4):419-431.

8. Srivastava AK, Mishra S. Blood dyscrasia in a teleost fish, Colisa fasciatus, associated with cadmium poisoning. Journal of comparative pathology. 1979;89(4):609-613.
9. Ruparelia SG, Verma Y, Metha WS, Saiyad SR, Kashyap SK. Study on haematological parameters in fresh water fish Sarotherodon mossambicus (Peters) exposed to cadmium. J Rec Adv App1 Sci. 1986;1:135-138.

10. Ruparelia G, Verma Y, Saiyad SR, Rawal UH. Haematological assessment of fresh water fish Sarotherodon mossambicus (Peters) under the influence of cadmium. J Natcon. 1989;1:55-63.

11.Wintrobe MM. Hemolytic anemias. In: Clinical Haematology. Henry Kimpton,London.1987:621.

12. McLeay DJ. Effects of a 12-hr and 25-day exposure to Kraft pulp mill effluent on the blood and tissues of juvenile Coho salmon (Oncorhynchus kisutch). J Fish Res Board Can. 1973;30(3):395-400.

13. Larsson A. Some biochemical effects of cadmium on fish. In Sublethal Effects of Toxic Chemicals on Aquatic Animals, Proceedings of the Swedish Netherlands Symp. 1975.

14.Gardner GR, Yevich PP. Histological and hematological responses of an estuarine teleost to cadmium. J Fishs Res Board Can. 1970;27(12):2185-2196.

15. Singh SR, Singh BR. Effect of copper and zinc sulfate on the blood parameters of Mystus vittatus. Matsya.1982;8:1-6.

16. O'Connor DV, Fromm PO. The effect of methyl mercury on gill metabolism and blood parameters of rainbow trout. Bull Environ Contam Toxicol. 1975;13(4):406-411.

17. Larsson A, Lehtinen KJ, Haux C. Biochemical and hematological effects of a titanium dioxide industrial effluent on fish. Bull environ contam toxicol. 1980;25(3):427-435.

18. Haniffa MA, Isaiarasu L. Influence of Paper Mill Effluents on Haematological Changes of the Mystus armatus. 1985:12-18.

19. Haniffa MA, Murugesan AG, Porchelvi M. Hematological effects of distillery and paper mill effluents on Heteropneustes fossilis (Bloch) and Sarotherodon mossambicus (Peters). Proceedings: Animal Sciences. 1986;95(2):155-161.

20. Lett PF, Farmer GJ, Beamish FWH. Effect of copper on some aspects of the bioenergetics of rainbow trout (Salmo gairdneri). J Fish Res Board Can. 1976;33(6):1335-1342.

21. Kumaraguru AK, Beamish FWH. Bioenergetics of acclimation to permethrin (NRDC-143) by rainbow trout. Comp Biochem Physiol C. 1983;75(2):247-252.

22. McKim JM, Christensen GM, Hunt EP. Changes in the blood of brook trout (Salvelinus fontinalis) after short-term and long-term exposure to copper. J Fish Res Board Can. 1970;27(10):1883-1889.

23. Christensen GM. Effects of metal cations and other chemicals upon the in vitro activity of two enzymes in the blood plasma of the white sucker, Catostomus commersoni (Lacepede). Chem Biol Interact. $1972 ; 4(5): 351-361$ 